\title{
Myself When Others: Daphne du Maurier and the Double Dialogue with 'D'
}

\author{
Avril Horner and Sue Zlosnik
}

\section{Daphne du Maurier and the paternal legacy}

One of the most powerful influences on Daphne du Maurier's life and writing was her relationship with her actor-manager father, whom she referred to as ' $D$ '. Her life was in part defined by a theatrical legacy which - in spite of the fact that her mother had acted professionally when young - she associated with the male side of the family. Her writing constantly returns to the complexities of familial relationships and often does so through tropes of disguise or masquerade, by dramatic moments of performance that are revelatory within the scheme of the narrative, and in some instances by the use of plays and players. We see this characteristic of her writing as one manifestation of a dialogue with her paternal legacy. Nina Auerbach, who refers to the 'essential theatricality of all the du Mauriers', has argued persuasively for the enduring influence on Daphne du Maurier of her literary grandfather, the novelist and Punch cartoonist, George: 'her entire fictional canon can be seen as an extended revised biography of George du Maurier’. In this essay, however, we shall focus mainly on her artistic relationship with her father, Gerald, whose personal and professional life Daphne wrote about so vividly and affectionately in her biography published soon after his death in 1934, Gerald: A Portrait.

Myself When Young, published over forty years later in 1977 when Daphne du Maurier was seventy and her father and grandfather had been dead for many years, identifies her sparkling paternal lineage and compares it with a rather dull maternal inheritance. Both George and Gerald were vital, creative, energetic men; both became 
intensely emotionally attached to one of their daughters. Daphne du Maurier's 'Aunt May' (Marie Louise), one of five siblings, apparently had a 'special' relationship with her father George; he adored her as 'the true daughter of his dreams' and she was heartbroken when he died in 1896. ${ }^{\text {ii }}$ Gerald du Maurier became similarly attached to Daphne, the middle of his three daughters. According to Margaret Forster, 'There was an empathy between the two of them which was quite unmistakable'. iii Angela, Daphne's older sister, notes in Old Maids Remember that 'there was a very special affinity between our father and Daphne'. $\quad$ Gerald, who had dearly wished for a son to carry on the family artistic tradition, made Daphne his favourite, partly no doubt because he saw in her a continuation of his own father's literary talents. We have elsewhere explored how her relationship with the masculine ‘creative’ side of her family might have led Daphne du Maurier to construct her literary imagination as the 'masculine’ side of herself - her 'boy-in-the box'; this, in turn, resulted in a sense of split self, illustrated most clearly in her best-selling novel Rebecca. ${ }^{\mathrm{v}} \quad$ In this essay we intend to explore du Maurier's ambivalence about her intense relationship with her actor father and how it might have marked her writing in other ways; we shall also explore how the writing itself - because it probes the tensions between love, desire and hatred - might have functioned both to resolve such feelings and to give voice, simultaneously, to deep concerns about the various ways in which fathers threaten daughters.

Obviously we are not the first to be interested in the impact of fathers upon daughters who write. In a recently published essay, Meg Jensen notes how Virginia Woolf frequently echoes the preoccupations of her father's life (which included mountaineering as well as scholarship) in her choice of trope - perhaps as a way of negotiating the difficulty of usurping the father's control of the word and of dealing with his heavy presence in her life. In Jensen’s words ‘The tropes she chose to articulate that 
divide [scaling mountains in the fresh air and working in stuffy libraries] illustrate the contradictory nature of that influence'. ${ }^{\text {vi }}$ As Jensen and many others have pointed out, Woolf was acutely aware of the complex nature of her feelings for her father:

It was only the other day when I read Freud for the first time that I discovered that this violently disturbing conflict of love and hate is a common feeling; and is called ambivalence. ${ }^{\text {vii }}$

Daphne du Maurier’s relationship with Gerald du Maurier was rather different from that between Woolf and her father but we see in her work the same tendency to echo in her fiction the preoccupations of the father's life - here acting and the theatre and the same deep ambivalence. Emotionally distant from her mother, whom she thought of as 'the Snow Queen in Disguise', viii Daphne du Maurier adored her father uncritically when a child. Indeed, she records in Myself When Young how his desire to watch the air-raids from the roof-top of their London house during 1917 terrified her and led her to cry out 'Don’t go...don’t go...Don’t ever leave me’ (MWY, p.35). However, she found his love oppressive as she grew older. Forster records how Gerald would spy on Carol Reed kissing Daphne when he brought her home and would pry into what they had been up to sexually - and she also notes his distress on hearing of his daughter's decision to marry Tommy ('Boy’) Browning. ${ }^{\text {ix }}$ In Gerald: A Portrait, Daphne du Maurier describes how 'he would watch in the passage for his own daughter to return, and question her hysterically, like one demented, if the hands of the stable clock stood at half past two' ${ }^{\mathrm{x}}$ She also notes the despair he felt when rejected by his daughters: It is the tragedy of every father and every daughter since the world began. But he took it harder than most. He brooded upon it, and nursed it in his mind. It gave him a little added bitterness which was peculiar to him and strangely pathetic. $^{\text {xi }}$ 
The original title of Myself When Young, which was - significantly - Growing Pains: The Shaping of a Writer, suggests that even in her seventies du Maurier still felt a pressing need to explore the roots of her ambivalent feelings for her father. Not surprisingly, the shadows of her grandfather as writer and her father as actor haunt the pages of this memoir, based on diaries kept from childhood until her late twenties. A voracious reader in her youth, du Maurier began writing her first book (The Alternative) at the age of thirteen - the same year in which she began to menstruate - an event described graphically in the opening of chapter 3, 'Adolescence', and noted as a particularly unwelcome 'growing pain' (MWY, pp.45-8). There is, from here on in the memoir, a tension between a strong sense of affiliation with the masculine creative side of the du Maurier family and a desire to become her own woman: a sense of the self as psychologically 'split' is already evident. As she becomes more independent, she nevertheless feels even more strongly linked to the memory of her grandfather, who had died before her birth, through their shared love of literature and of Paris (MWY, pp.103, 111, 112). On finding his diary for 1867 (when she was twenty-three years old), she notes that her mood swings seem to echo his and comments 'Yes, perhaps we were alike' (MWY, p.146). At times she sees him re-created in her writing self: 'if I was ever to write another Trilby...I must get to work' (MWY, p.89) and, indeed, her first published novel, The Loving Spirit, was launched by Doubleday, Doran \& Co. Inc in 1931 as a work by 'the daughter of the actor Gerald du Maurier and grand-daughter of George du Maurier, who wrote Trilby and Peter Ibbetson' (MWY, p.151). It is interesting to note that at this point she had already begun work on her second novel. One of her darkest works, The Progress of Julius contains a forceful grandfather and charts a father's suffocating love for his daughter.

In Myself When Young, du Maurier describes her love for her father; how they 
both enjoyed games and the outdoors (Gerald took pleasure in sailing all his life although he was basically a metropolitan creature) and how they both loved acting. Even as a small child, du Maurier found acting, like literature, a therapeutic solution to emotional tension:

I saw why D. like to dress up and pretend to be someone else; I began to do it myself...It was a strange thing, but the very act of putting on fancy dress and becoming another person stopped the feeling of panic when visitors came. (MWY, p.19)

One of her childhood pleasures was acting out plays and films with her father and sisters at home. Later, she rationalises her creation of an alter ego, Eric Avon, and her identification with the narrators of her novels, as deriving from an ability she has inherited from her father: 'acting, after all, was in my blood' (MWY, p.53). This talent becomes then fused with her identity as a writer: 'Act God. Fashion men and women as Prometheus fashioned them from clay, and, by doing this, work out the unconscious strife within and be reconciled' (MWY, p.58).

\section{Intimacy and Anxiety}

The 'unconscious strife' referred to here, however, derived not just from the difficulty of wishing to be a famous woman writer in a family in which creativity had been so far demonstrated only by men. It also derived from her complex feelings about her father's desire for intimacy with her. When she was about eighteen years old, Daphne du Maurier borrowed a life of Cesare Borgia from Hampstead Library ( $M W Y$, p.82). According to many biographies (including presumably this one) Cesare Borgia was reputed to have committed incest with his sister, Lucrezia, the illegitimate daughter of Pope Alexander VI. Alexander himself was also, by many sources, reputed to have 
slept with his daughter. In Myself When Young, the word 'Borgia' becomes used as a trope to signal awareness of an increasingly uneasy intimacy with both her older cousin, Geoffrey, and her father, Gerald. From early adolescence, du Maurier became the focus of Geoffrey's sexual attention. At the age of fourteen, she noticed that he smiled at her in a particular way; at this time he was thirty-six years old and married. By the time she was twenty, he was kissing her passionately on the mouth. Describing what she calls her 'first experience' - presumably of a man kissing her erotically - du Maurier records:

It seems so natural to kiss him now, and he is very sweet and lovable. The strange thing is it's so like kissing D. There is hardly any difference between them. Perhaps this family is the same as the Borgias. D. is Pope Alexander, Geoffrey is Cesare, and I am Lucretia. A sort of incest. (MWY, p.108) Although she begins to find Geoffrey’s description of their love as ‘sacred’ (MWY, p.110) rather embarrassing, she remains fond of him. Even when dating Carol Reed, du Maurier describes Geoffrey as 'still a brother. Brother and son. Such a muddle’ (MWY, p.127). The same sort of 'muddle’ is evident in her relationship with Gerald, who is described as ‘the Borgia father' (MWY, p.110) and whose jealousy of her suitors du Maurier sees as unhealthily possessive. On one level, her marriage to Major 'Boy' Browning resolved the 'muddle' for her: on the last page of Myself When Young we read: 'For henceforth I would come to know what it was to love a man who was my husband, not a son, not a brother' (p.157).

The 'muddle', however, continued to inform her fiction, which allowed her to 'work out the unconscious strife within and be reconciled'. What evolves over the years is a sort of double dialogue with the paternal legacy. On the one hand, her conscious strategy - borne out of her interest in Jung and Adler in the 1950s - enabled her to 
construct her writing self as masculine; a self that had to be locked away most of the time but which emerged, when she wished to be creative, as the boy-in-the-box or as a 'disembodied spirit'. She also came to realise that her fiction allowed her to express some of her deepest anxieties and conflicts. In an unpublished letter written to Meaburn Staniland (designer of the jacket covers for the 1960s Penguin editions of her novels), in which she reflected on her writing career, she wrote:

I discovered I was working out my own problems in fantasy, although each book told a different story, and the result was that I became suddenly lost...the shock was so intense I nearly went off my rocker. ${ }^{\text {xii }}$

On the other hand, however, the paternal legacy continued to inspire and inform her writing in ways that suggest a continuing unconscious negotiation with her father's personality and his influence upon her. This side of the double dialogue results in some of her darkest works. They 'reconcile' inner strife in plots that invariably shock readers, even now.

\section{The Progress of Julius}

The Progress of Julius, written by du Maurier when she was only 24 and originally published by Heinemann in 1933 (reprinted by Arrow in 1994 as Julius), still has this power to shock. This tale of parental obsession therefore predates the biography of Gerald and presents a much darker picture of father/daughter relations. Julius Lévy, son of an Algerian Jewish father and French mother, is brought up by his parents and grandparents in relative poverty in a small village on the banks of the Seine. His grandfather is a practical man, whereas his father Paul - a dark-eyed, pale, rather strange man - is dreamy and impractical, escaping from the problems around him through his flute-playing into a land of enchantment and beauty. Even as a child, Julius feels torn 
between his French Blançard self - a self that wishes to make money and get on (and which he identifies with his grandfather) - and his Jewish self, which responds to spirituality and to beauty, which is more like his father. After a traumatic childhood, in which he and his family are driven out of their village by the Prussians (he sees his grandfather killed before his eyes) and his father murders his mother in a crime of passion, Julius flees to Algeria with his father. Here Paul dies and Julius is taken under the wing of the local rabbi. Moving later to London as a young man, he works desperately hard and by the time he is in his early thirties his resourcefulness has made him very wealthy. He marries the daughter of a rich acquaintance, for convenience rather than love, and they have a child. Julius has very little to do with his daughter whilst she is growing up, being kept busy by his flourishing business empire, his social life and various mistresses. It is only when he is aged fifty, feeling bored and irritable, that Gabriel, his daughter, has a sudden impact on his life. She has been away at school for some time and Julius returns home one day to hear her playing his father's flute; the moment is an epiphany for him and Gabriel's performance thus becomes the turning point of the narrative. The music reminds him of his father and evokes his more artistic and spiritual side that has become submerged by his social identity as a ruthless businessman. However, this hitherto repressed aspect of himself becomes transmuted into a powerful erotic charge that he experiences as desire for his daughter:

he looked at her, her face, her body, her hands on the flute, the colour of her hair; he looked at her figure outlined against the window, and a fierce sharp joy came to him stronger than any known sensation, something primitive like the lick of a flame and the first taste of blood, as though a message ran through his brain saying: 'I for this - and this for me'. xiii

Julius subsequently develops a ‘voracious passion’ ( $J$, p.213) for Gabriel, placing 
Rachel, his wife, in a position of sexual rivalry with her own daughter, whose precocity adds to her pain. Instead of sending her away to 'finishing' school, Julius decides to take charge of the next three years of Gabriel's life and they enter upon an orgy of spending on hunting, flat-racing and yachting. The novel carefully avoids any description of actual sexual abuse but it is clear that Gabriel's playing of her grandfather's flute induces fantasies for Julius that verge on the sexual:

'Do you like that, Papa?'... and he was in the room again, back in the world, startled as though with the first shock of waking, the sight of her standing there so cool and undisturbed jarring upon him who felt dissatisfied and unrefreshed, an odd taste in his mouth, and a sensation in mind and body that was shameful and unclean. ( $J$, pp.225-226)

Their language and behaviour towards each other become that of lovers rather than parent and child: Julius buys his daughter extravagant presents and he calls her 'a bitch' when she upsets him. He even thinks of his daughter as a replacement wife: deciding that Rachel's 'utility was over now' he is pleased that 'Gabriel would make as a good a hostess when she came out next year' ( $J$, p.232). Gabriel, too, is excited by her father's sophistication and worldly power, which make young men look 'callow and inexperienced' ( $J, p .238)$; yet the emotional intensity of their relationship is clearly inappropriate and verges on the abusive. Indeed, Gabriel's perception of that relationship is expressed in du Maurier's narrative through metaphors of penetration and surfeit:

She had no will of her own now, no consecutive thought, no power of concentration; she was being dashed and hurtled into a chaos that blinded her, some bottomless pit, some sweet, appalling nothingness... He was cruel, he was relentless, he was like some oppressive, suffocating power that stifled her and 
could not be warded off; he gave her all these bewildering sounds and sensations without pausing so that she was like a child stuffed with sweets cloying and rich; they were rammed down her throat and into her belly, filling her, exhausting her, making her a drum of excitement and anguish and emotion that was gripping in its savage intensity. It was too much for her, too strong. ( $J$, pp.243-244) Rachel, her mother, has meanwhile developed cancer and falls into despair; she finally commits suicide by taking an overdose. Free now to indulge his love for his daughter, Julius feels reinvigorated and sees Gabriel as 'the ideal companion, the other self' (J, p.254). However, he becomes unable to cope with his jealousy of her suitors, and not wishing to share her with anyone else, arranges a boat trip from Cannes and strangles her with his own handkerchief whilst she is swimming. ${ }^{\text {xiv }}$ Gabriel thereby pays a terrible price for her complicity with the father. The world assumes that Julius Lévy’s daughter has drowned tragically at sea; the novel ends with Julius degenerating into a lonely old age and finally dying from a stroke.

The Progress of Julius clearly resonates with George du Maurier’s novel Trilby in that the plots of both novels involve music, Jewishness and a young woman who is exploited by a ruthless older man. But there are other resonances to be explored. In desiring his daughter, Julius expresses a repressed desire for an alter ego associated with all that his construction of himself as a 'Jewish' businessman has obscured: beauty, art, spirituality. Julius feels himself to be 'split', then, just as Daphne did. However, in replacing his wife with Gabriel, Julius also demonstrates the dysfunctional nature of his love for his daughter. He is Gabriel's protector and her murderer. Svengali’s quasi-Gothic 'otherness' and his ruthless exploitation of a young woman for his own ends are translated within Daphne du Maurier’s novel into a dark tale in which a father emotionally and sexually abuses his daughter. In both cases the plot is dominated by a 
charismatic, manipulative and emotionally demanding older male.

Significantly, years later in the mid 1960s, when writing Vanishing Cornwall and remembering the moment of sudden realization - experienced long ago - that Cornwall was where she would spend the rest of her life, Daphne du Maurier was to recall 'a line from a forgotten book, where a lover looks for the first time upon his chosen: "I for this, and this for me"' ${ }^{\mathrm{xv}}$ In fact, as we have seen, these are the exact words that spring to Julius's mind when he sets eyes upon his young adult daughter and realizes how much he desires her. Remarkably, du Maurier seems to have forgotten that she had herself written this striking sentence, indicating a curious process of authorial repression at work. The Progress of Julius is an implicit indictment of how the father/daughter romance can evolve into a relationship in which the daughter might be quite literally loved to death. Daphne du Maurier, a strong character, confronted her father's emotional possessiveness through defiance; Gabriel becomes, horrifyingly, victim to the father's will. Although she later became interested in reclaiming the shadowy figure of the mother, at this point in her career du Maurier is more concerned with the overwhelming presence of the father. Seen in this light, The Progress of Julius is not only part of an on-going dialogue du Maurier conducted with her artistic and literary grandfather but is also part of a continuing unconscious conversation with her flamboyant, emotionally demanding and manipulative father. The Progress of Julius is, perhaps, her first attempt to exorcise her desire for, and fear of, the father. Desire because the father represents everything she wishes to be herself: creative and artistic. Fear because she could be overwhelmed by his charisma and his emotional demands and thus not survive as writer herself. This is something recognised by many women writers whose fathers were creative and charismatic: in her mid forties Virginia Woolf noted that if her father had lived into old age 'His life would have entirely ended mine. 
What would have happened? No writing; no books; -inconceivable. ${ }^{\text {xvi }}$ The plot of The Progress of Julius represents du Maurier's deepest unconscious fears: she must struggle to break free from her much-loved father otherwise her artistic self will die. The sense of ambivalence is stark.

\section{Father figures}

Despite this early attempt to 'work out the unconscious strife within and be reconciled', du Maurier remained haunted by the power of the father and continued throughout her writing career to deal with it in different ways. Maxim, of course, is almost twice the age of the nameless narrator in her most famous novel and many critics (including ourselves) have commented on the father-daughter dynamic of the relationship between Maxim and his second wife - 'a husband is not so very different from a father', he tells her. ${ }^{\text {xvii }}$ The novel's emotional complexity derives not only from the 'muddle' of the narrator's relationship with Maxim but also from a sense of self that, for most of the novel, is presented as fragile, layered and, increasingly, split and doubled. In this respect, it is interesting that Rebecca contains one of the most dramatic scenes of masquerade and performance in the whole of du Maurier's work. As we have argued elsewhere, a key moment in Rebecca occurs when the insipid second Mrs de Winter becomes a 'moving picture'. Bringing an ancestral portrait to life in Gothic fashion, she transforms herself consciously into Lady Caroline de Winter and unconsciously into Rebecca. ${ }^{\text {xviii }}$ So convincing is the act that it delivers a profound shock to Maxim and the reader is alerted by the layers of identity incorporated in the image - the second wife dressed as Rebecca dressed as Maxim’s ancestor - that the relationship between the second and first wife is far from simple. In this book the 'other' will become eventually absorbed into the 'self' in such a way 
as to affect Maxim's role as husband as the narrator's as wife. The resolution is thus the eventual displacement of the father-daughter relationship by a mother-son dynamic (the older narrator cares for her invalid husband in a maternal way and the sexual passion seems to have evaporated from their relationship). One 'muddle' replaces another, in effect. A more apparently light-hearted example of masquerade is Frenchman's Creek, du Maurier's 1941 novel (the only one she acknowledged to be romantic), in which Lady St Columb dresses as a man and sails with her French pirate, a man who is simultaneously dangerous and refined. For a short time she indulges her desire to be both like and with this romantic figure who presents a very different aspect to the lawlessness of the grimy ‘fair traders' of Jamaica Inn. Du Maurier's tendency to 'peg', as she called it, her characters on to real people was a conscious process; she wrote to her friend Oriel Malet in 1962 that she had 'pegged' the pirate onto the unlikely figure of 'Christopher' Puxley, a man with whom (according to Margaret Forster’s biography) she had been having a romantic relationship. $^{\text {xix }}$ The most significant piratical figure of her life, however, was her father in the guise of Captain James Hook in Peter Pan, a role for which he was renowned; the glamorous French pirate perhaps had a darker, unconscious 'peg' too.

\section{The Parasites}

In 1949, du Maurier was to publish her novel about a theatrical family. An undeservedly neglected work, The Parasites draws on her own experiences of the world of the theatre. The parasites of the title are three adult siblings, children of a famous singer father and dancer mother; they are dubbed such by the conventional husband of the oldest, Maria, herself a successful actress. Sheila Hodges, for many years du Maurier's editor, describes The Parasites as 'one of the most interesting of 
the sixteen novels which Daphne du Maurier wrote’. According to Hodges:

it is fascinating for the light it throws on Daphne herself, and on the many facets of her very complex personality. In later years she said how much of herself she had put into the portraits of the siblings, and there are striking parallels between episodes in this book and passages both in her biography of her father (Gerald) and in the account of her early life which she wrote over forty years later (Growing Pains). ${ }^{\mathrm{xx}}$

One of the most interesting strategies of the novel is the shifting narrative voice. When referring to one of the siblings it is third person, when referring to them collectively, it moves into the first person plural. Hodges notes this shifting narrative voice but states that she had never discussed the matter with du Maurier and did not know whether it had been deliberate or not. No reviewer, she says, seemed to notice

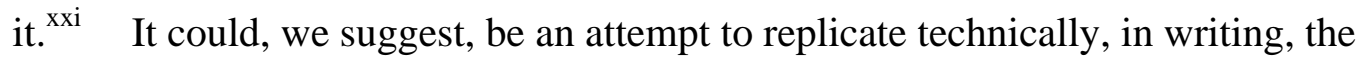
'muddle' of identity, particularly within the complex dynamic of family life. Where does the 'self' stop and the 'other' begin? How far is one’s own identity predicated upon that of others? What constitutes the boundary between self and other, between familial love and sexual desire? Where does first person end and third person begin? The shifting narrative voice could also, of course, indicate a plural and performative notion of identity being played out through the novel. Either way, any sense of identity as singular and coherent is undermined by The Parasites. Indeed, in the three Delaneys, Maria, Niall and Celia, the competing aspects of 'Daphne' are clearly visible in a dramatization of the self as fractured. The youngest, Celia, is the nurturer who cares for her widowed father, the mercurial and demanding 'Pappy', until his death, 'Mama' having met an untimely end. She never breaks out of the paradigm of the dutiful daughter but transfers her need to nurture to her sister's 
children. Showing artistic talent herself, she never fulfils her potential because her inscription into the familial narrative overrides the artistic impulse and any professional imperative it might imply. This ‘death’ of a creative self - intimated more dramatically by the actual death of Gabriel in The Progress of Julius - is something du Maurier feared deeply until the end of her days.

The oldest of the three, Maria, is the professional performer who, when everything in her life seems to be falling apart - when her parents are dead and her husband is about to divorce her, claiming custody of the children - is able to remember her father's words; 'do the work you feel in your bones you have to do, because it's the only damn thing you can do, the only thing you understand' (p.305). ${ }^{\text {xxii }}$ Taunted by her soon to be ex-husband with the words; 'you're not an individual at all, you're just a hotch potch of every character you've ever acted' $(P$, p.14), her 'individuality' - what preserves her as a functioning subject - is that very power to be herself when others. In her case, as in Gerald's, this is found in the theatre:

In the theatre there was safety. A deep embedded sense of home, of safety. The dressing-room that needed doing up, with the plaster coming off the walls, the dusty ventilator. The crack in the basin. The worn bit of carpet that the rug could not cover....The only safety lay in subterfuge. In doing what she had done from the beginning of time. In pretending to be someone else...( $P$, p.257)

For du Maurier, safety lay in writing, in pretending 'to be someone else' on the page. But the writer is rather different from the actor since the writer also tells the story, sets the scene and creates the narrator as well as the characters. The writer is director and producer as well as player: the writer, in fact, 'acts God' in a way that an actor cannot. 
The writer is therefore is able to reconcile emotional conflict through plot as well displacing feelings onto others. For example, in du Maurier's representation of Maria there are moments when she seems to be drawing on her own adolescence in order to explore female sexuality and familial desire. The seduction of the pubescent Maria on the beach in Brittany by the much older Michel (P, pp.71-73) has clear echoes of the attentions paid to the fourteen-year old du Maurier by Geoffrey Miller. Perhaps Niall is the saddest of the three main characters. Possessing an easy talent that makes him a popular composer of light music, Niall is characterised by an undisciplined artistic impulse that makes him persistently unhappy. His quasi-incestuous love for his 'sister' Maria adds to the muddle in his mind and represents unfulfilled desire. It is quasi-incestuous because he and Maria are in fact not biologically related. 'Our relationship to each other was such a muddled thing that it was small wonder no one reached the truth of it correctly', says the first person plural narrative voice early in the novel ( $P, \mathrm{p} .18)$. Niall is, apparently, Mama's son by someone else, a pianist 'who had disappeared out of her life' ( $P$, p.19). His dreaminess and slightly exotic looks suggest a legacy similar to that of Paul Lévy; his masculine creativity reminds us of Daphne du Maurier's own 'boy in the box' Eventually choosing Freada, his step-father's first wife, as a lover, he continues the emotional 'muddle' of his life by keeping sexual desire within the family, so to speak. The novel ends with his impending death, a death less Gothic than the walling up of Dick in The King's General three years earlier but no less tragic for that. Niall's death might or might not be suicide as he drifts out to sea in a lamentably unprepared small boat that is rapidly taking in water; his final thoughts are not of Maria but of the family servant who had looked after him as a child. 'He thought of kind, comfortable Truda, and of her broad safe lap' ( $P$, p.317). She is clearly the maternal nurturing 
figure to whom in the end he wants to return but who also represents oblivion: 'The sea was another Truda, upon which he could cast himself when the time came, without anguish and without fear' $(P$, p.317). Du Maurier presents Niall as irreparably damaged, and finally destroyed, by a family that loves dysfunctionally: Maria sees him as her 'reflection in the mirror' but also as 'the scapegoat, bearing all her sins' ( $P$, p.100). The failure to establish a firm border between self and 'sister' proves, in the end, tragic. Death at sea, metaphorically a return to the oceanic pre-symbolic realm, to a time before the borders of the self have been drawn, indicates both release and defeat.

\section{'A Border-Line Case'}

Daphne du Maurier returned to the theme of boundaries and of incestuous desire in the late short story significantly entitled A Border-Line Case (1971). Avoiding the representation of knowing incest, the tale is constructed along the lines of a Greek tragedy in which the protagonists are unaware of each other's true identity until catastrophe overtakes them. Plays and players are essential to the plot: its heroine is a professional actress and Shakespeare's dark comedy, Twelfth Night, a play that hinges on masquerade and gender confusion, is used to provide the tragic turn of the story. The kind man whom the aspiring actress Shelagh Money had believed to be her father has died and she sets out on a journey to find his old naval friend and best man, the now reclusive Nick Barry, described to her by her father as, 'Gallant as they come, but mad as a hatter. A border-line case'. xxiii The search for Nick takes her into deepest rural Ireland to Ballyfane, where, posing as a journalist called Jennnifer Blair (actually her stage name), she makes enquiries about 'Commander Barry’ and finds the inhabitants stolid and taciturn. Virtually 
kidnapped by the Commander's men, Shelagh discovers a small community run with naval precision and efficiency by the charismatic Nick. She sees her parents' wedding photograph in Nick's comfortable sitting room but is disturbed by the fact it has been tampered with:

Nick’s head and shoulders had been transposed on to her father's figure, while her father’s head...had been shifted to the lanky figure behind, standing between the bridesmaids. (DLN, p.125)

In the manner of all Greek tragedies, she fails to see the significance of this clue but experiences ‘a feeling of revulsion, a strange apprehension' and reflects that 'the room that had seemed warm and familiar became kinky, queer. She wanted to get out of it' (DLN, p.125). For the reader this uncanny moment sounds an ominous warning note. However, when she meets Nick she is reassured and becomes fascinated by him. Far from having withdrawn from life, it transpires that he is responsible for organising covert terrorist activities. Taking Shelagh with him on a bombing raid over the border into Northern Ireland he uses the opportunity of a long ride in the back of a van to make love to her. She is entirely willing and the sex is good. Falling asleep afterwards, she dreams about the man she believed to be her father. He is waving goodbye to her as she boards the train to return to boarding school and she calls out in the dream 'Don't go...don't ever leave me' (DLN, p.148) exactly the same words du Maurier was to recall - a few years later in Myself When Young - having called out to her father when a child of ten. Once again, we see a curious process of authorial repression at work in du Maurier’s writing. In 'A Border-Line Case', it is only after her return home that Shelagh discovers the truth that her mother and Nick had had an affair, resulting in her birth - only then does the reader understand the significance of her 'father's' last words - 'Oh, no...Oh, 
Jinnie...Oh, my God' (DLN, p.101). Only he had called her by this diminutive of her stage name and the exclamation had been uttered just as she had struck a pose as Cesario for a forthcoming production of Twelfth Night. In catching sight of his 'daughter’ anticipating her stage role as a boy, Mr Money had recognised the features of his own friend; indeed, it is intimated that it was this 'truth' that finally killed him. Here again is a terrible moment of insight in which performance and disguise reveal a profoundly disturbing truth. At the end of the story it is Nick's gift of a photo of himself in that very role decades earlier that reveals the truth to Shelagh. In his features she sees her own. The revelation that she has indeed slept with her own father is traumatic for her and precipitates her into a self-loathing that urges her towards indiscriminate violence. Already psychologically fragile ('She was neither Shelagh nor Jinnie, she was Viola-Cesario’ ( $D L N$, p.159)) she is, the story implies, mentally destroyed by her experience of incest. Her having burst into tears at the side of the newly uncovered megalithic tomb suggests, in retrospect, that some things might have been better left undisturbed. 'A Border-line Case' is a tale built up from a tissue of deceptions cleverly represented through tropes of performance and representation in the form of the stage and the photograph. They are both duplicitous: at one and the same time fake and truth-telling.

\section{Conclusion}

As, of course, is fiction. In seeing herself as acting God and fashioning 'men and women as Prometheus fashioned them from clay’, du Maurier found not only 'safety' in 'subterfuge'; she also found autonomy and power - the power to write a story that somehow made sense of the 'muddle' of life. Like Virginia Woolf, who wrote 'I did for myself what psycho-analysts do for their patients. I expressed some 
very long felt and deeply felt emotion. And in expressing it I explained it and then laid it to rest', ${ }^{\text {xiv }}$ du Maurier recognised the healing power of writing, of her ability to reconcile 'the unconscious strife within' through authorship. In displacing the strife onto others, she sought to resolve conflicts within that otherwise might have destroyed her. In that sense she realised, like many writers, that her work was therapeutic. But, like all good writing, her work is more than mere therapy. She skilfully dramatises, in disguised form, the emotional muddle of her own life and gives us novels and stories which are gripping and disturbing. They challenge sentimental narratives of family life, asking us to consider at what point, and how, love can become dysfunctional and damaging. They also pose enduring questions concerning the relationship between author and character and between 'self' and 'other'.

i Nina Auerbach, Daphne du Maurier; Haunted Heiress (Philadelphia: University of Pennsylvania, 2000) p. 53 and. p. 29.

ii See Daphne du Maurier, Gerald: A Portrait (London: Victor Gollancz, 1934) pp. 44.

iii Margaret Forster, Daphne du Maurier (London: Chatto and Windus, 1993) p. 12.

iv Angela du Maurier, Old Maids Remember (London: Peter Davies, 1966) p. 138.

v Avril Horner and Sue Zlosnik, Daphne du Maurier: Writing, Identity and the Gothic Imagination (Basingstoke: Macmillan, 1998).

vi See Meg Jensen, 'The Anxiety of Daughterhood: Re-examining Bloom's theory of influence in the work of Louisa May Alcott and Virginia Woolf' , Compass Vol. 4 (July 20 
2007). On-line link:

http://www. blackwe11-compass. com/subject/1iterature/section_home?section=1ico-a20th $\underline{\text { century }}$

We wish to thank Meg Jensen for sharing her ideas with us before the publication of her work, when we were drafting our lecture for the Daphne du Maurier International Centenary Conference held at Fowey, $10^{\text {th }}-11^{\text {th }}$ May, 2007. Those ideas provided an initial and important stimulus for this essay.

vii Virginia Woolf, 'A Sketch of the Past' in Moments of Being ed. Jean Schulkind (London: Hogarth Press, 1928) p. 108.

viii Daphne du Maurier, Myself When Young: The Shaping of a Writer (1977; London: Arrow Books, 1993) p. 51. Hereafter page references to this work (abbreviated as MWI) will be given in the text.

ix Margaret Forster, Daphne du Maurier, pp. 63 and 94.

x Daphne du Maurier, Gerald, p. 215

xi Daphne du Maurier, Gerald, p. 255.

xii This letter, together with others by du Maurier, came up for auction at Sotheby' s in 1997. They were bought by a private collector. The letter is dated $5^{\text {th }}$ May 1962.

xiii Daphne du Maurier, Julius (London: Arrow Books, 1994) p. 211. Hereafter page references to this work (abbreviated as $J$ ) will be given in the text.

xiv There are obviously echoes here of Shakespeare's Othello, in which jealousy and a handkerchief are key elements.

xv Daphne du Maurier, Vanishing Cornwall (Harmondsworth: Penguin Books, 1967), p. 6.

The Diary of Virginia Woolf Vol. III ed. A. 0. Bell (London: Hogarth, 1977), p. 208.

xvii

Daphne du Maurier, Rebecca (London: Arrow, 1992) p. 211.

xviii

Avril Horner and Sue Zlosnik, “"Moving Pictures” : Family Portraits, Gothic 
Anxieties and Daphne du Maurier' s Rebecca' in Andrew Smith, Diane Mason and William Hughes (eds), Fictions of Unease: The Gothic from Otranto to the X Files (Bath: Sulis Press, 2002) pp. 170-182.

xix As Forster notes in her biography of du Maurier, Puxley' s real name was Henry Puxley. However, du Maurier called him 'Christopher' and herself 'Jane' , names perhaps adapted from her novel The Loving Spirit (Daphne du Maurier, pp. 155, 156 and 433).

xx Sheila Hodges, 'Editing Daphne du Maurier' , Women's History Review 11:2, (2002) 293-308. See also Sheila Hodges, 'Editing Daphne du Maurier' in Helen Taylor (ed.), The Daphne du Maurier Companion (London: Virago, 2007) in which she comments, à propos of The Parasites, '(Du Maurier) was fascinated by the phenomenon of incest, which is a recurring thread in her books - not from the sexual aspect, but as a manifestation of the urge that she believed exists in all of us to get back to our families' (p.30).

xxi

Ibid., p. 294.

xxii Daphne du Maurier, The Parasites (1949; Harmondsworth: Penguin Books, 1965) p. 305. Hereafter page references to this work (abbreviated as $P$ ) will be given in the text.

xxiii Daphne du Maurier, Don' t Look Now (Harmondsworth: Penguin, 1973) p. 108. 'A Border-Line Case' was first published by Gollancz in 1971 in the collection Not After Midnight and Other Stories; the same collection was published by Penguin Books in 1973 as Don' $t$ Look Now. Hereafter page references to this work (abbreviated as DLM) will be given in the text.

xxiv Virginia Woolf, 'A Sketch of the Past' , Moments of Being ed. Jeanne Schulkind (Triad Books, p. 94). 